\title{
Origin of the Multiple-Sourced Cherts in Maokou Carbonates in Sichuan Basin, South China
}

\author{
Haofu Zheng ${ }^{1, *}$, Junfeng Wu ${ }^{1}$, Hailei Tang ${ }^{2}$, Bo Liu ${ }^{2,3, *}$, Xiangyang Yang ${ }^{1}$, Kaibo Shi ${ }^{3}$, Kaiping Luo ${ }^{4}$, Qi Qiu ${ }^{4}$ \\ and Yixin Dong 5
}

check for updates

Citation: Zheng, H.; Wu, J.; Tang, H.; Liu, B.; Yang, X.; Shi, K.; Luo, K.; Qiu, Q.; Dong, Y. Origin of the Multiple-Sourced Cherts in Maokou Carbonates in Sichuan Basin, South China. Minerals 2021, 11, 1269. https://doi.org/ $10.3390 / \min 11111269$

Academic Editors: Avraam Zelilidis, Ioannis Iliopoulos and Georgia Pe-Piper

Received: 1 October 2021

Accepted: 11 November 2021

Published: 15 November 2021

Publisher's Note: MDPI stays neutral with regard to jurisdictional claims in published maps and institutional affiliations.

Copyright: (C) 2021 by the authors. Licensee MDPI, Basel, Switzerland. This article is an open access article distributed under the terms and conditions of the Creative Commons Attribution (CC BY) license (https:/ / creativecommons.org/licenses/by/ $4.0 /)$.
1 College of River and Ocean Engineering, Chongqing Jiaotong University, Chongqing 400074, China; wujunfeng@mails.cqjtu.edu.cn (J.W.); yangxy@cqjtu.edu.cn (X.Y.)

2 School of Earth Sciences, Yunnan University, Kunming 650091, China; highlytang@yeah.net

3 School of Earth and Space Sciences, Peking University, Beijing 100871, China; shikaibo@pku.edu.cn

4 Wuxi Research Institute of Petroleum Geology, SINOPEC, Wuxi 214126, China;

Luokp.syky@sinopec.com (K.L.); Qiuqi.syky@sinopec.com (Q.Q.)

5 State Key Laboratory of Oil and Gas Reservoir Geology and Exploitation, Chengdu University of Technology, Chengdu 610059, China; dongyixin008@hotmail.com

* Correspondence: zhenghaofu@cqjtu.edu.cn (H.Z.); bobliu@pku.edu.cn (B.L.)

\begin{abstract}
Cherts have been thought to originate from biosilicification, terrestrial inputs and hydrothermal activity. The study of cherts is helpful in understanding the paleo-ocean environment and tectonic-sedimentary processes. Large amounts of cherts occur widely in the Maokou Formation in the Sichuan Basin, which may be largely connected to the Permian Chert Event (PCE). However, the source of silica and the formation process of cherts remain debated. Here, we analyze the petrographic and geochemical features of the cherts from the Guadalupian Maokou Formation ( 268-259 Ma) in six sections in the Sichuan Basin. Two main types of cherts, nodular and bedded, are recognized in the Maokou Formation. The formation of nodular cherts was mainly affected by hydrothermal fluids, whereas the bedded cherts are mainly of biogenetic origin. The Emeishan large igneous province (ELIP) caused the activation of deep faults, accompanied by intense hydrothermal activities. Correspondingly, the cherts of significant hydrothermal origin developed near the active deep faults. The intensified hydrothermal activities may provide extra silica supplies and flourish the silica-secreting organisms by the associated volcanogenic upwellings that facilitated the enrichment of cherts. The study of Maokou cherts can help to record the volcanic- and silicon-related biological activities in the eastern Paleo-Tethys Ocean and can provide significant implications for chert enrichment in analogous settings.
\end{abstract}

Keywords: cherts; hydrothermal; biogenetic; Maokou; ELIP

\section{Introduction}

Cherts have attracted wide attention because they were formed under specific geochemical conditions, which are of great significance in the reconstruction of the paleo-ocean environment, paleotectonic activity and paleogeography [1-5]. During the Permian period, cherts were extensively deposited along the northeastern Panthalassic Ocean, called the Permian Chert Event (PCE) [6-10], which is attributed to the upwellings associated with ice melting at high latitudes [6,7]. PCE has been reported in many regions around the world, such as New Zealand, Oman, Greece, Italy, Thailand, North America and China [6-9], and is believed to have been caused by the special paleo-ocean environment.

The widespread Guadalupian cherts in the Yangtze Block in southern China are considered to be a response to PCE [4,5,11-14]. However, the origin of cherts has been associated with biological processes, terrestrial inputs and hydrothermal activity [15-21]. Furthermore, current studies overwhelmingly believed that the major formation of the Guadalupian cherts in the Upper Yangtze area was related to biosilicification and hydrothermal activity caused by regional tectonic and volcanic activity [4,22-24]. The Emeishan large 
igneous province (ELIP) occurred simultaneously with the enrichment of the Guadalupian cherts $[25,26]$, suggesting a genetic link [22,24]. Alternatively, the Guadalupian cherts were formed under the influence of the silicon-rich hydrothermal fluids and volcanogenic upwellings, and they mainly accumulated in the stretched troughs related to the ELIP [5]. However, the Guadalupian cherts are characterized by multiple occurrences and heterogeneous spatial distribution, and the previous studies mainly concentrated on the cherts in the northwestern Upper Yangtze region, limiting the full explanation of the enrichment of the Guadalupian cherts.

To understand the formation mechanism thoroughly, we collected Guadalupian chert and host limestone samples from several outcrops in the Sichuan Basin. Systematic petrological and geochemical (element compositions and stable silicon isotopes) analyses were carried out to explore the siliceous sources and triggering factors for the formation of various types of cherts, and we propose a reasonable conceptual model for the origin of Guadalupian cherts in the Sichuan Basin.

\section{Geological Setting}

The Sichuan Basin is located on the Upper Yangtze Block in South China and has experienced multiple periods of tectonic movement (Figure 1) [27]. In the Guadalupian, the sedimentary facies of the Sichuan Basin were mainly a shallow-water carbonate platform, with extensive shoals in the central and western regions of the basin [28]. The ELIP event on the Upper Yangtze platform (Figure 1B) occurred during the Guadalupian, and the main eruption time was $\sim 260-257 \mathrm{Ma}$ [29]. The associated basalts are mainly distributed in the southwestern regions, and a small number of basalts have also been discovered near the basement faults in the central Sichuan Basin [30]. The subduction of the Jinshajiang-Mojiang Ocean Basin from south to north triggered the ELIP events and caused the extensional tectonic environment of the Upper Yangtze platform [31,32]. Therefore, the structure-sedimentary differentiation, namely a deep-water trough development on the shallow-water carbonate platform, appeared in the northern part of the basin (Figure 1C). Dark-colored argillaceous limestones were deposited in the trough, containing many nodular or bedded cherts [5,22]. In addition, massive dolomites were found in the Middle Permian successions, mostly interpreted as hydrothermal dolomites formed by the hydrothermal fluids from the activated deep faults $[5,22,33]$.

The Middle Permian succession includes the Liangshan Formation $\left(\mathrm{P}_{2} \mathrm{l}\right)$, Qixia Formation $\left(\mathrm{P}_{2} \mathrm{q}\right)$ and Maokou Formation $\left(\mathrm{P}_{2} \mathrm{~m}\right)$ in the Sichuan Basin. The Maokou Formation can be subdivided into four members from bottom to top: Mao1, Mao2, Mao3 and Mao4 (Figure 2). The Mao1 member is mainly composed of micrite and argillaceous limestone, indicating a relatively deep-water sedimentary environment, which may be related to the large transgression that occurred on the Yangtze platform in the early Maokou period. In contrast, bioclastic limestone and dolomite developed in the Mao2 member, indicating the formation of shallow shoals under high-frequency sea-level changes. The deposition of the Mao3 and Mao4 members reflects the sedimentary differentiation pattern of troughplatform facies. In the central and southern regions of the Sichuan basin, the Mao3 and Mao4 members mainly consist of dolomite and bioclastic limestone. In contrast, in the extensions of the trough, the Mao3 and Mao4 members are mainly composed of argillaceous limestone and shale, accompanied by a large number of bedded and nodular cherts $[28,33]$. Besides, numerous bedded and nodular cherts developed in the Mao3 and Mao4 members in the deep-water facies in the periphery of the platform (Figure 2). 

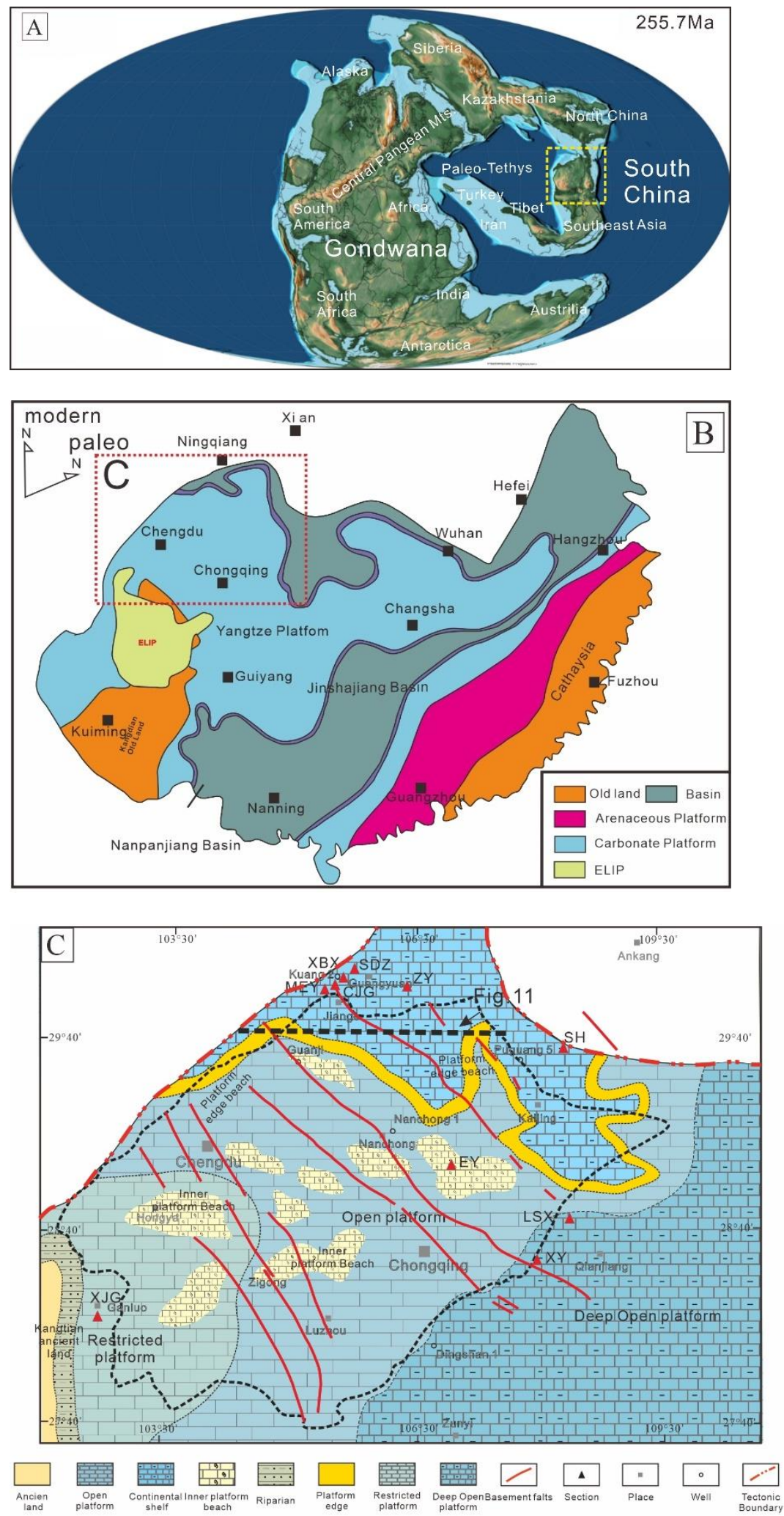

Figure 1. (A) Middle Permian ( 255.7 Ma) global paleogeography and the location of Sichuan Basin, South China [34]. (B) Middle Permian paleogeography of the Upper Yangtze Block [22,35,36] and the location of the Sichuan Basin. (C) Maokou paleogeography of Sichuan Basin (basement faults from [37]). XY: Xiaoyan, EY: Erya, SH: Shuanghe, XBX: Xibeixiang, SDZ: Sanduizhen, ZY: Zhengyuan, LSX: Lengshuixi, XJG: Xinjigu; MEY: Maeryan. 


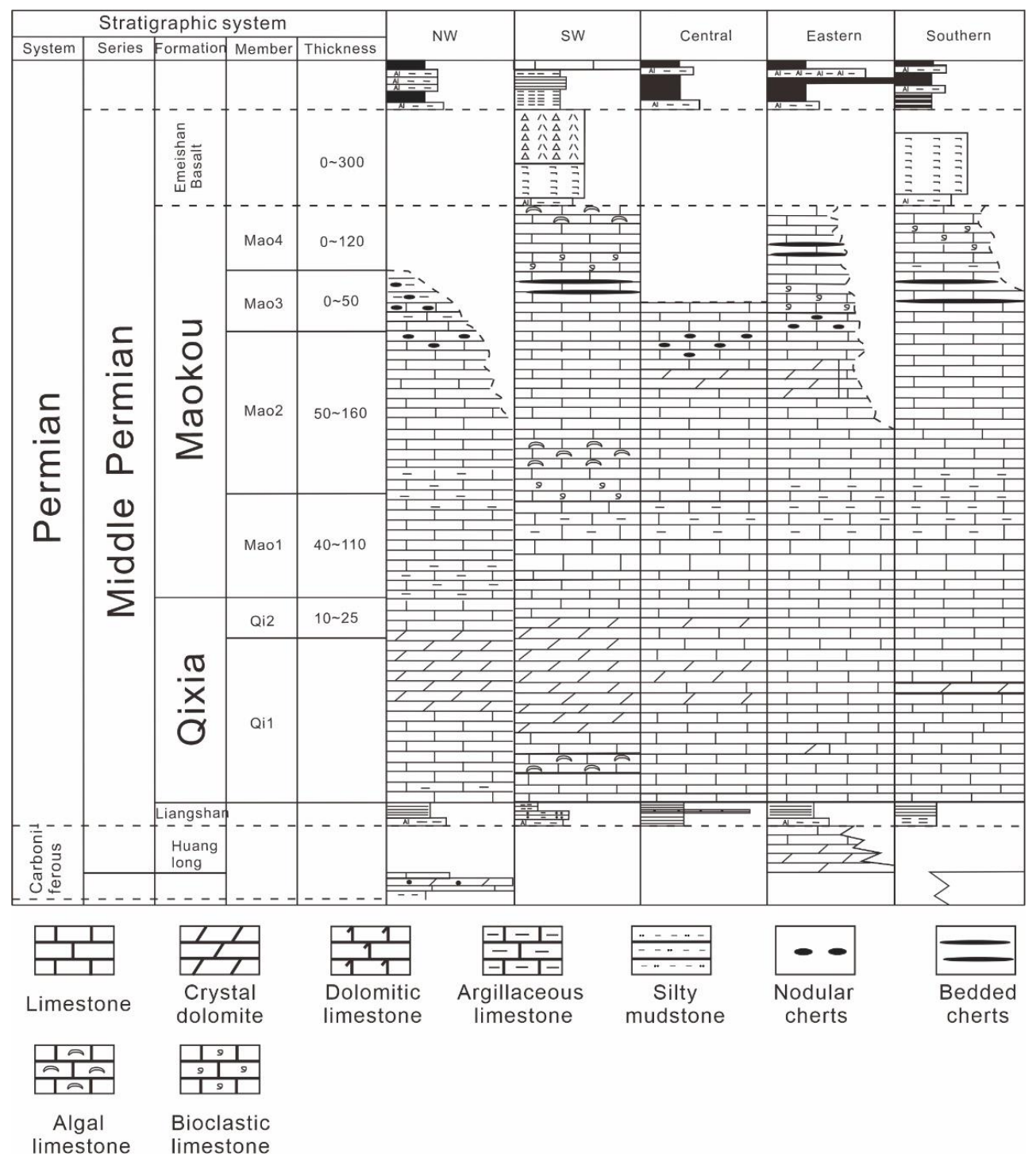

Figure 2. The comprehensive stratigraphic column of the Middle Permian in the Sichuan Basin (modified from [38]).

\section{Materials and Methods}

A total of 15 chert samples and six host limestone samples of the Maokou Fm. were collected from the Changjianggou section (CJG; $32^{\circ} 19^{\prime} 25^{\prime \prime} \mathrm{N}, 105^{\circ} 27^{\prime} 9^{\prime \prime} \mathrm{E}$ ), Maeryan section (MEY; $\left.32^{\circ} 16^{\prime} 23^{\prime \prime} \mathrm{N}, 105^{\circ} 25^{\prime} 3^{\prime \prime} \mathrm{E}\right)$, Xibeixiang section (XBX; $32^{\circ} 31^{\prime} 35^{\prime \prime} \mathrm{N}, 105^{\circ} 44^{\prime} 42^{\prime \prime} \mathrm{E}$ ), Sanduizhen section (SDZ; 32 $\left.28^{\prime} 54^{\prime \prime} \mathrm{N}, 105^{\circ} 38^{\prime} 23^{\prime \prime} \mathrm{E}\right)$, Shuanghe section (SH; $31^{\circ} 57^{\prime} 04^{\prime \prime} \mathrm{N}$, $108^{\circ} 39^{\prime} 28^{\prime \prime}$ E), Zhengyuan section (ZY; $\left.32^{\circ} 22^{\prime} 44^{\prime \prime} \mathrm{N}, 106^{\circ} 18^{\prime} 39^{\prime \prime} \mathrm{E}\right)$, Xiaoyan section (XY; $29^{\circ} 28^{\prime} 11^{\prime \prime} \mathrm{N}, 107^{\circ} 55^{\prime} 26^{\prime \prime}$ E) and Erya section (EY; 30 $32^{\prime} 42^{\prime \prime} \mathrm{N}, 106^{\circ} 49^{\prime} 17^{\prime \prime}$ ) (Figure 1C). Detailed petrographic studies on 40 thin sections were carried out at the School of Earth and Space Sciences, Peking University. The thin sections were stained with Alizarin Red $\mathrm{S}$ to identify silica from calcite. Afterward, the chert and limestone samples were conducted with an FEI- QUANTA650FEG scanning electron microscope (SEM) with a working current of $10 \mathrm{kV}$ and a distance of $11.4 \mathrm{~mm}$ at the Peking University's Key Laboratory of Orogenic Belts and Crustal Evolution (OBCE). After selecting and washing the samples, they were crushed to powders by an agate mortar and pestle to below 200 mesh for geochemical analyses.

The major and trace elements were analyzed at the OBCE at Peking University. The samples were microfragmented by a dental drill to eliminate the interference of veins or 
other minerals and were screened by a 200-mesh sieve. For the analysis of major elements, $2 \mathrm{~g}$ sample powders and lithium tetraborate were mixed into a fused glass with a ratio of 1:8. Then the fused glass was measured by a Thermo Arl Advant'XP X-ray fluorescence spectrometry $(\mathrm{XRF})$. The accuracy and precision of the data were better than $2.5 \%$.

The analysis of trace and rare earth elements required $0.5 \mathrm{~mL}$ concentrated $\mathrm{HNO}_{3}$ to dissolve and then dry the $50 \mathrm{mg}$ sample powders. The dried sample was dissolved in $5 \mathrm{~mL}$ of $\mathrm{HNO}_{3}$ with a concentration of $1.42 \mathrm{~g} / \mathrm{mL}$ and was heated for $3 \mathrm{~h}\left(\right.$ at $\left.130^{\circ} \mathrm{C}\right)$. Then, the heated solution was diluted to $60 \mathrm{~mL}$ by adding ultra-pure $\mathrm{H}_{2} \mathrm{O}$ for trace element testing. The contents of trace and rare earth elements were determined by using an inductively coupled plasma mass spectrometer (ICP-MS, Agilent 7500, USA). For the standardization of REE data, we used the data of Post-Archean Average Shale (PAAS). The anomalies of Eu and Ce were calculated by the following formulas: $\mathrm{Ce} / \mathrm{Ce}^{*}=\mathrm{Ce}_{\mathrm{SN}} /\left(0.5 \mathrm{LaSN}_{\mathrm{SN}}+0.5 \mathrm{Pr}_{\mathrm{SN}}\right)$ and $\mathrm{Eu} / \mathrm{Eu}^{*}=\mathrm{Eu}_{\mathrm{SN}} /\left(0.67 \mathrm{Sm}_{\mathrm{SN}}+0.33 \mathrm{~Tb}_{\mathrm{SN}}\right)[39]$.

The $\mathrm{Si}$ isotope analyses were carried out at the Institute of Mineral Resources, Chinese Academy of Geological Sciences. Chert samples were dissolved with $\mathrm{HCl}$ at $500{ }^{\circ} \mathrm{C}$ to remove other components of the sample, such as carbonate or organic components. Afterward, $\mathrm{SiF}_{4}$ was formed in a metallic vacuum line by reacting with $\mathrm{BrF}_{5}$. Then, we purified the obtained $\mathrm{SiF}_{4}$ gas by using a $\mathrm{Cu}$ tube with $\mathrm{Zn}$ particles at $60^{\circ} \mathrm{C}$. Finally, the ratios of the $\mathrm{Si}$ isotope were tested by a MAT-253 gas source isotopic mass spectrometer. According to the NBS-28 reference material, the silicon isotopic compositions were recorded as $\delta^{30} \mathrm{Si}(\mathrm{Rsam}=$ the value of the sample, Rstd $=$ the value of the reference material):

$$
\delta^{\mathrm{X}} S i=\left(\frac{R_{\text {sam }}}{R_{\text {std }}}-1\right)(\text { in permil })
$$

GBW04421 and GBW04422 were used as two standard materials to be tested together with the samples and the secondary standard samples (AGV-2, andesite) in the experiment, which both had better long-term reproducibility than $\pm 0.1 \%$ ( $2 \sigma)$ [40-42].

\section{Results}

\subsection{Petrography of Cherts}

The Maokou cherts hosted within limestones display uneven thickness (Figure 3A-I). The most common types of cherts are nodular and bedded cherts (Figure 3). Bedded cherts are mainly developed in the Erya (EY), Luomuhe (LMH), Lengshuixi (LSX), Shuanghe (SH), Xibeixiang (XBX) and Zhengyuan (ZY) sections (Figure 3A,B,D), which are interbedded with micrite limestone (Figure 3A,B) or argillaceous limestone layers (Figure 3D). The bedded cherts are composed of microcrystalline quartz and abundant siliceous organism fragments, including spicules, radiolarians and ostracods (Figures $4 \mathrm{E}$ and $5 \mathrm{~B}$ ). The structures of skeletal grains (e.g., spicules, radiolarians) were legible and preserved perfectly (Figure 5C,D). 


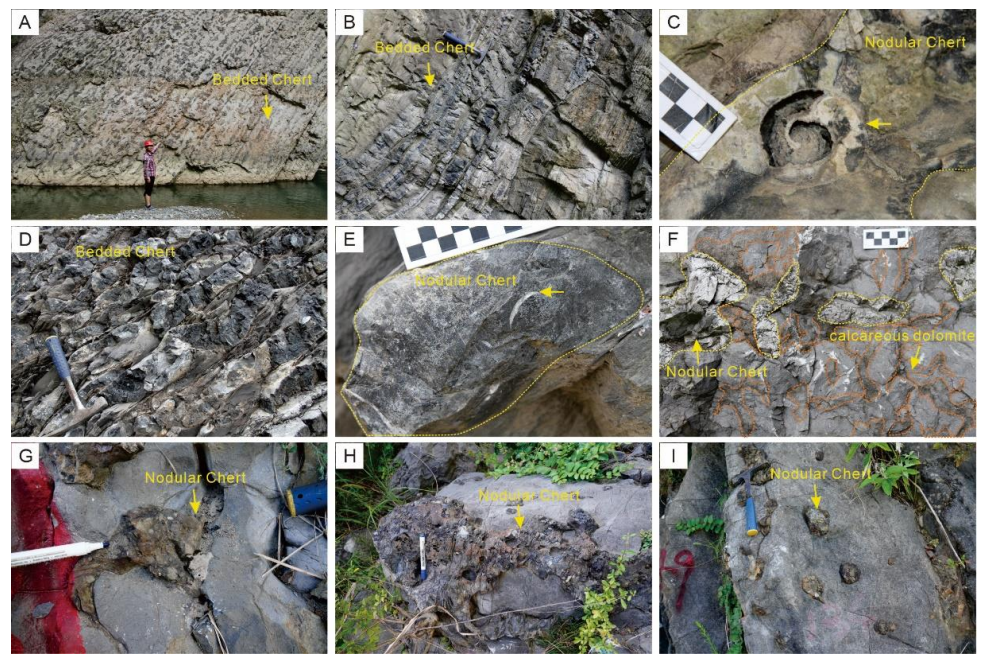

Figure 3. Photos of different outcrops showing bedded and nodular cherts of the Maokou Formation. (A) Bedded cherts at $\mathrm{SH}$ section; (B) bedded cherts at $\mathrm{SH}$ section; (C) nodular chert (length = $12 \mathrm{~cm}$; height $=3 \mathrm{~cm}$ ) is wrapped by host limestones at MEY section. A gastropod fragment is well preserved; (D) bedded cherts are interbedded with the argillaceous limestone at EY section; (E) nodular chert $(\mathrm{L}=18 \mathrm{~cm} ; \mathrm{H}=9 \mathrm{~cm})$ is wrapped by limestone at LSX section. A calcareous brachiopod fragment is preserved; (F) nodular chert and calcareous dolomite are wrapped by host micrite limestone, MEY section; (G-I) nodular cherts show different sizes in the thick micrite-bioclastic limestone at the MEY section.
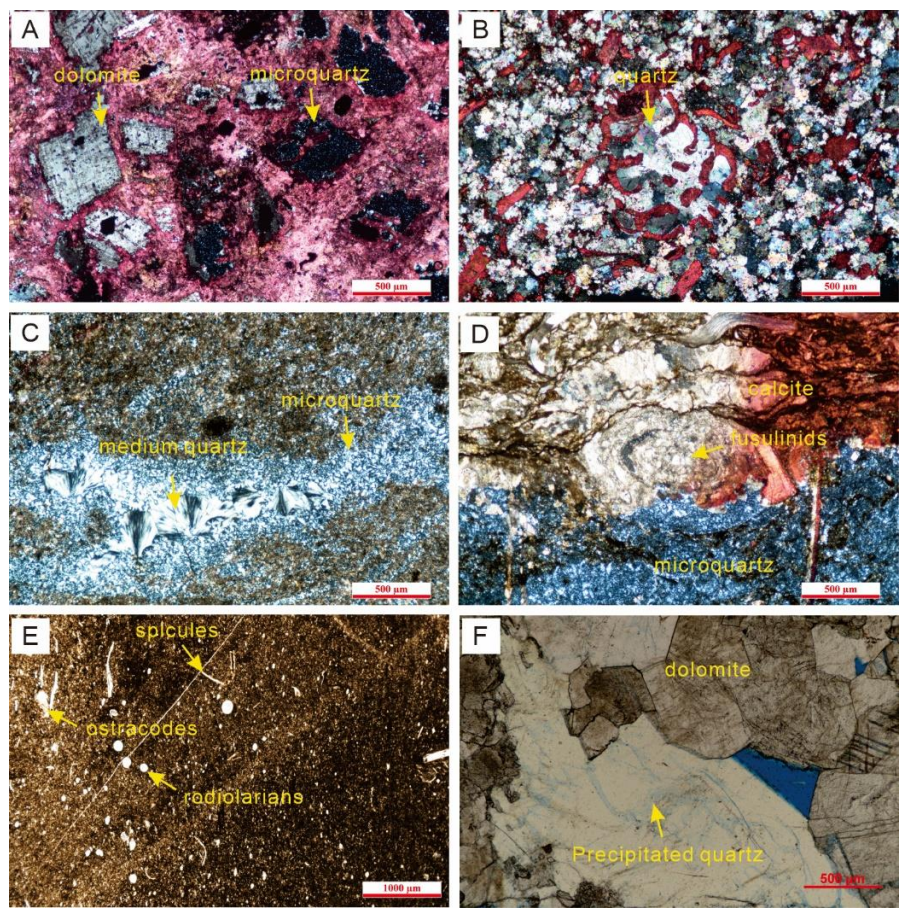

Figure 4. Microscope photos show the characteristics of the Maokou cherts. (A) Dolomites in the silicified limestone, MEY section; (B) bioclasts are silicified into fine to medium crystalline quartz in the host limestone, MEY section; (C) silica recrystallization is found in microfracture, MEY section; (D) boundary between chert and host limestone, fusulinids and other bioclasts were partially silicified into microquartz, MEY section; (E) bedded chert contains a large number of siliceous organisms, including spicules, ostracodes and radiolarians, SH section; $(\mathbf{F})$ precipitated quartz appears in the intergranular pores of dolomites, XJG section. 

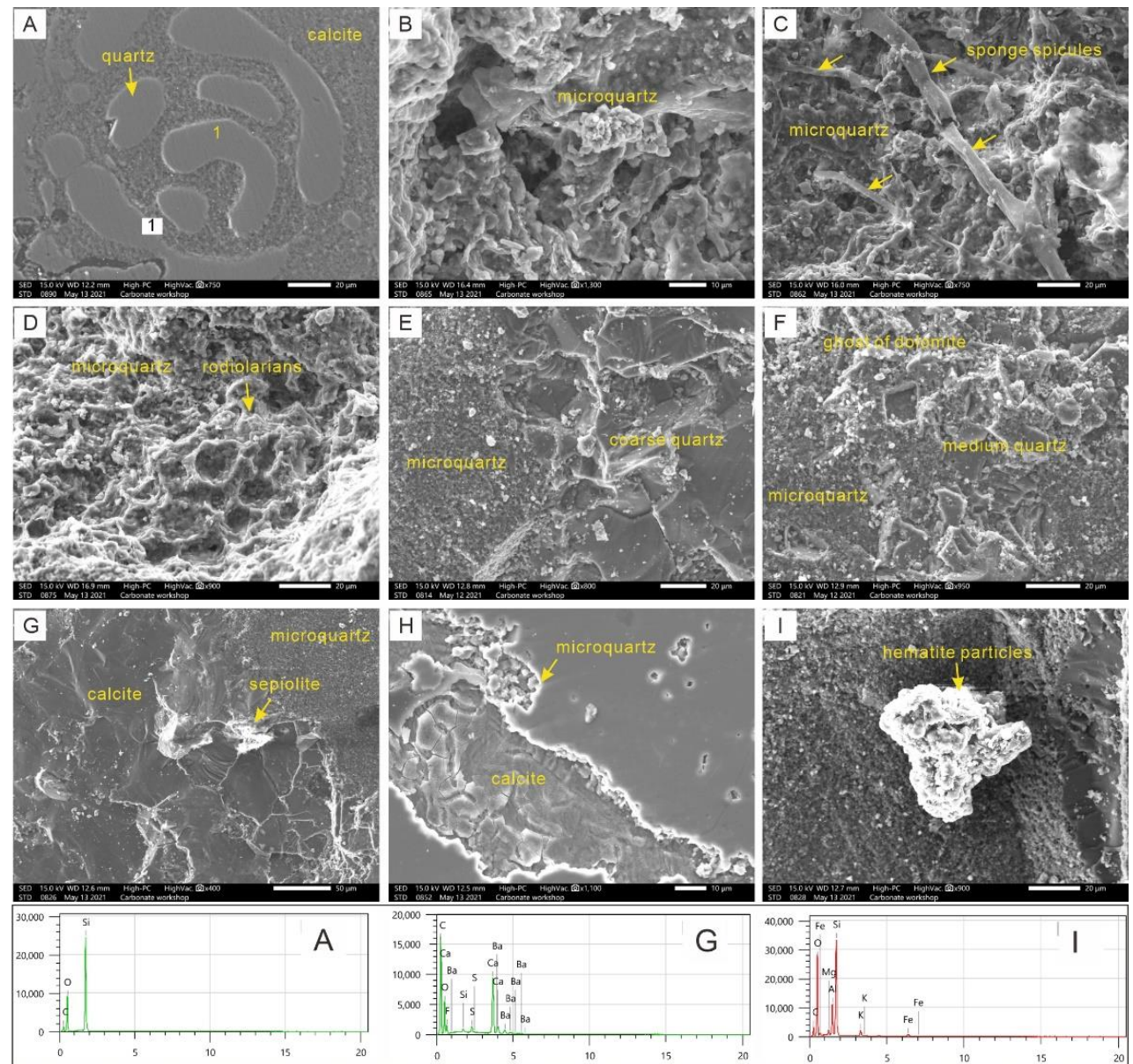

Figure 5. SEM photographs of studied Maokou cherts and host limestones. (A) Bioclasts were silicified into quartz in the host limestone, MEY section; (B) bedded chert composed of microquartz, EY section; (C) abundant sponge spicules (yellow arrows) in bedded chert, SH section; (D) radiolarians in bedded chert occurred as microquartz, LSX section; (E) silica recrystallization to medium crystalline quartz close to the microquartz, MEY section; (F) ghost dolomite in nodular chert, MEY section; (G) sepiolite occurs within intergranular pores of a calcitic nodular chert, MEY section; $(\mathbf{H})$ calcite filled a microfracture in nodular chert, MEY section; (I) hematite in the nodular chert, MEY section.

Nodular cherts are mainly found in Maerya (MEY) and Xiaoyan (XY) sections. Most nodular cherts show dark gray or brownish-yellow colors due to exposed weathering or oxidization (Figure 3E-I). Some calcareous gastropod and brachiopod fragments were preserved in the nodular cherts and were partially silicified (Figure $3 \mathrm{C}, \mathrm{E}$ ). The calcareous dolomites appeared to be close to the nodular cherts that were wrapped by host micrite limestone in the Maokou Fm. (Figure 3F). At the MEY section, fusulinids and other bioclasts were partially silicified near the boundary between the chert and host limestone (Figure 4D). In addition, many small rhombic dolomite grains were found in the host limestone near the nodular cherts at Maokou Fm. (Figure 4A). SEM observation shows that calcareous organisms (foraminifera, etc.) were replaced by fine-grained quartz aggregates in the host limestone (Figure 5A). The microcrystalline quartz was recrystallized to medium size (Figure 5E). Clean precipitated quartz appears in the dolomite of Maokou Fm. in the Xinjigu (XJG) section (Figure 5F). 


\subsection{Geochemistry}

\subsubsection{Major and Trace Elements}

The $\mathrm{SiO}_{2}$ contents of the bedded cherts in the Maokou Fm. span from $77.96 \%$ to $93.30 \%$ (average $87.12 \%$ ) (Table 1 ). The $\mathrm{Fe}_{2} \mathrm{O}_{3}$ concentrations of the bedded cherts range from $0.04 \%$ to $0.48 \%$ (average $0.19 \%$ ), and $\mathrm{Al}_{2} \mathrm{O}_{3}$ content ranges from $0.05 \%$ to $0.32 \%$ (average $0.27 \%$ ). The contents of $\mathrm{TiO}_{2}$ are relatively low, varying from $0.002 \%$ to $0.023 \%$ (average $0.009 \%$ ). The $\mathrm{SiO}_{2}$ concentrations of the nodular cherts range from $74.89 \%$ to $97.30 \%$ (average $88.41 \%$ ), which are similar to those of bedded cherts. The range of $\mathrm{Fe}_{2} \mathrm{O}_{3}$ and $\mathrm{Al}_{2} \mathrm{O}_{3}$ content of the nodular cherts are from $0.02 \%$ to $1.54 \%$ (average $0.0 .74 \%$ ) and $0.06 \%$ to $1.19 \%$ (average $0.35 \%$ ), respectively. $\mathrm{The}_{\mathrm{TiO}}$ contents of the nodular cherts are slightly higher than those of the bedded cherts, varying from $0.010 \%$ to $0.055 \%$ (average $0.025 \%$ ).

Table 1. Major elements of the Maokou cherts and limestones in the Sichuan Basin.

\begin{tabular}{|c|c|c|c|c|c|c|c|c|c|c|c|}
\hline Sample & Occurrence & $\begin{array}{c}\mathrm{SiO}_{2} \\
(\mathrm{wt} \%)\end{array}$ & $\begin{array}{l}\mathrm{Al}_{2} \mathrm{O}_{3} \\
(\mathrm{wt} \%)\end{array}$ & $\begin{array}{c}\mathrm{TFe}_{2} \mathrm{O}_{3} \\
(w \mathrm{t} \%)\end{array}$ & $\begin{array}{c}\mathrm{CaO} \\
(w \mathrm{t} \%)\end{array}$ & $\begin{array}{c}\mathrm{MgO} \\
(\mathbf{w t} \%)\end{array}$ & $\begin{array}{c}\mathrm{K}_{2} \mathrm{O} \\
(w \mathbf{w} \%)\end{array}$ & $\begin{array}{l}\mathrm{Na}_{2} \mathrm{O} \\
(\mathrm{wt} \%)\end{array}$ & $\begin{array}{l}\mathrm{MnO} \\
(\mathbf{w t} \%)\end{array}$ & $\mathrm{TiO}_{2} \%$ & $\begin{array}{l}\mathrm{P}_{2} \mathrm{O}_{5} \\
(\mathbf{w t} \%)\end{array}$ \\
\hline EY-1 & bedded & 81.598 & 0.256 & 0.117 & 9.278 & 1.946 & 0.025 & 0.023 & 0.004 & 0.006 & 0.010 \\
\hline EY-2 & bedded & 82.36 & 0.4 & 0.48 & 9.5 & 0.08 & 0.12 & 0.03 & 0.01 & 0.02 & 0.01 \\
\hline EY-4 & bedded & 89.67 & 0.31 & 0.06 & 5.28 & 0.12 & 0.06 & 0.06 & 0 & 0.01 & 0.02 \\
\hline LSX-4 & bedded & / & / & / & / & / & I & / & / & I & / \\
\hline LSX-5 & bedded & I & I & I & I & I & I & I & I & I & I \\
\hline LSX-1 & bedded & 77.96 & 0.1 & 0.18 & 11.5 & 1.21 & 0.03 & 0.06 & 0 & 0 & 0.02 \\
\hline SH-1 & bedded & 82.68 & 0.32 & 0.22 & 6.87 & 2.19 & 0.05 & 0.03 & 0.01 & 0.01 & 0.01 \\
\hline $\mathrm{SH}-3$ & bedded & 92.73 & 0.12 & 0.04 & 3.36 & 0.1 & 0.03 & 0.03 & 0 & 0.01 & 0 \\
\hline $\mathrm{XBX}-1$ & bedded & 91.4 & 0.48 & 0.28 & 1.28 & 0.15 & 0.09 & 0.04 & 0 & 0.02 & 0.06 \\
\hline ZY-1 & bedded & 92.4 & 0.15 & 0.16 & 4.01 & 0.03 & 0.02 & 0.03 & 0 & 0 & 0.02 \\
\hline $\mathrm{ZY}-2$ & bedded & 93.3 & 0.31 & 0.18 & 1.84 & 0.12 & 0.06 & 0.03 & 0.01 & 0.01 & 0.11 \\
\hline CJG-1 & limestone & 0.115 & 0.05 & 0.04 & 55.2 & 0.61 & 0.01 & I & 0 & 0.01 & 0 \\
\hline EY-3 & limestone & 0.197 & 0.04 & 0.03 & 55.5 & 0.34 & 0.01 & I & I & I & / \\
\hline LSX-2 & limestone & 2.899 & 0.06 & 0.02 & 53.4 & 0.82 & 0.01 & / & 0 & 0 & 0 \\
\hline SDZ-1 & limestone & 0.113 & 0.04 & 0.04 & 56 & 0.35 & 0.01 & I & I & I & I \\
\hline$X Y-2$ & limestone & 0.326 & 0.05 & 0.02 & 55.4 & 0.73 & 0.01 & I & I & I & 0 \\
\hline ZY-3 & limestone & 0.361 & 0.09 & 0.05 & 54.6 & 0.95 & 0.01 & I & 0 & 0 & I \\
\hline$X Y-1$ & nodular & 79.49 & 1.19 & 0.26 & 6.58 & 3.3 & 0.01 & 0.03 & 0 & 0.05 & 0.03 \\
\hline MET-1 & nodular & 74.89 & 0.06 & 0.2 & 12.5 & 2.61 & 0.01 & 1 & 0 & I & 0 \\
\hline MET-2 & nodular & 98.13 & 0.19 & 0.14 & 0.16 & 0.02 & 0.04 & I & 0.01 & / & 0.01 \\
\hline MET-3 & nodular & 87.14 & 0.19 & 1.51 & 4.75 & 1.45 & 0.04 & I & 0.18 & 0.01 & 0.01 \\
\hline MET-4 & nodular & 97.3 & 0.22 & 0.83 & 0.39 & 0.01 & 0.04 & 0.01 & 0.08 & 0.01 & 0.03 \\
\hline MET-5 & nodular & 89.55 & 0.28 & 0.81 & 2.2 & 0.14 & 0.04 & 0.06 & 0.07 & 0.03 & 0.01 \\
\hline
\end{tabular}

The Mn concentrations of the bedded and nodular cherts in the Maokou Fm. range from 3.9 to $85.4 \mathrm{ppm}$ (average $36.3 \mathrm{ppm}$ ) and from 19.7 to $1201 \mathrm{ppm}$ (average $588.4 \mathrm{ppm}$ ). The Co contents of the bedded cherts range from 0.2 to $396.6 \mathrm{ppm}$ (average $119.0 \mathrm{ppm}$ ), which are much higher than those of the nodular cherts with a range of 0.092 to 2.165 ppm (average $0.884 \mathrm{ppm}$ ) (Table 2). The range of the Cd contents of the bedded and nodular cherts are 0.038 to $5.908 \mathrm{ppm}$ (average $1.374 \mathrm{ppm}$ ) and 0.027 to $0.119 \mathrm{ppm}$ (average $0.074 \mathrm{ppm}$ ). The Mo contents of the bedded cherts (0.004 to $0.024 \mathrm{ppm}$; average $0.011 \mathrm{ppm}$ ) are lower than those of the nodular cherts (1.80 to $0.024 \mathrm{ppm}$; average $5.110 \mathrm{ppm}$ ). 
Table 2. Trace elements and stable silicon isotope compositions of the Maokou cherts and limestones in the Sichuan Basin.

\begin{tabular}{|c|c|c|c|c|c|c|}
\hline Sample & Occurrence & Cd(ppm) & Mo(ppm) & $\operatorname{Mn}(p p m)$ & Co(ppm) & $\delta^{30} \operatorname{Si}_{\text {NBS- } 28} \%$ \\
\hline EY-1 & bedded & 0.038 & 0.004 & 36.244 & 0.177 & 1.1 \\
\hline EY-2 & bedded & 0.1 & 0.03 & 46.63 & 173 & 1.1 \\
\hline EY-4 & bedded & / & / & / & / & 1.4 \\
\hline LSX-4 & bedded & / & / & / & I & 1.3 \\
\hline LSX-5 & bedded & / & / & / & / & 0.7 \\
\hline LSX-1 & bedded & 0.14 & 0.01 & 15.01 & 297 & / \\
\hline SH-1 & bedded & 0.97 & 0 & 74.56 & 0.69 & 0.2 \\
\hline $\mathrm{SH}-3$ & bedded & 0.07 & 0.02 & 15.18 & 397 & 1.1 \\
\hline $\mathrm{XBX}-1$ & bedded & 5.91 & 0.01 & 13.83 & 0.42 & / \\
\hline ZY-1 & bedded & 0.04 & 0.01 & 3.941 & 83 & 0.7 \\
\hline $\mathrm{ZY}-2$ & bedded & 3.73 & 0.01 & 85.38 & 0.51 & 0.6 \\
\hline CJG-1 & limestone & 0.26 & 0.01 & 35.9 & 0.52 & / \\
\hline EY-3 & limestone & 0.1 & 0.01 & 6.353 & 0.71 & / \\
\hline LSX-2 & limestone & 0.11 & 0 & 9.263 & 0.62 & / \\
\hline SDZ-1 & limestone & 0.15 & 0.01 & 6.416 & 6.63 & / \\
\hline$X Y-2$ & limestone & 0.17 & 0 & 6.928 & 0.59 & / \\
\hline $\mathrm{ZY}-3$ & limestone & 0.29 & 0.01 & 11.33 & 0.66 & / \\
\hline$X Y-1$ & nodular & 0.23 & 0.52 & 16.54 & 28.7 & 1 \\
\hline MET-1 & nodular & 0.12 & 1.8 & 19.7 & 0.33 & I \\
\hline MET-2 & nodular & 0.03 & 1.86 & 34.59 & 0.09 & / \\
\hline MET-3 & nodular & 0.06 & 3.4 & 1201 & 0.71 & I \\
\hline MET-4 & nodular & 0.06 & 3.97 & 653.5 & 1.12 & / \\
\hline MET-5 & nodular & / & / & / & I & I \\
\hline MET-6 & nodular & 0.104 & 5.110 & 1033.166 & 2.165 & I \\
\hline
\end{tabular}

\subsubsection{Rare Earth Elements}

The total rare earth elements (REEs) concentration of nodular cherts ranges from 0.38 to $8.33 \mathrm{ppm}$ (average $2.70 \mathrm{ppm}$ ), and the total contents of REEs of bedded cherts range from 0.53 to 17.14 ppm (average $5.51 \mathrm{ppm}$ ) (Table 3). The PAAS-normalized REEs of the Maokou cherts and limestone show a flat REE pattern (Figure 8). All chert samples in the Maokou Fm. display slightly negative $\mathrm{Ce} / \mathrm{Ce}^{*}$ values ranging from 0.88 to 0.99 (average 0.95), similar to those of Maokou limestones (0.94 to 0.99, average 0.97$)$. The Eu/Eu* values of the nodular chert samples exhibit high positive $\mathrm{Eu} / \mathrm{Eu}^{*}$ values ranging from 1.66 to 9.43 (average 5.38), whereas the $\mathrm{Eu} / \mathrm{Eu}^{*}$ values of the bedded chert samples exhibit slightly positive or negative values ranging from 0.95 to 2.73 (average 1.40). The Eu/Eu* values of the limestone samples exhibit slightly negative anomalies, ranging from 0.81 to 1.00 (average 0.91). 
Table 3. REE analysis results of the Maokou cherts and limestones in the Sichuan Basin (ppm).

\begin{tabular}{|c|c|c|c|c|c|c|c|c|c|c|c|c|c|c|c|c|c|c|}
\hline Sample & Occurrenc & ce La & $\mathrm{Ce}$ & Pr & Nd & Sm & Eu & Gd & $\mathrm{Tb}$ & Dy & Ho & Er & $\mathrm{Tm}$ & $\mathrm{Yb}$ & Lu & $\Sigma$ REE & $\mathrm{Ce} / \mathrm{Ce}^{*}$ & $\mathrm{Eu} / \mathrm{Eu}^{*}$ \\
\hline EY-2 & bedded & 0.491 & 0.898 & 0.114 & 0.414 & 0.091 & 0.022 & 0.085 & 0.013 & 0.082 & 0.017 & 0.050 & 0.007 & 0.053 & 0.008 & 2.347 & 0.915 & 1.341 \\
\hline LSX-1 & bedded & 0.082 & 170 & 0.022 & 0.087 & 0.023 & 0.012 & 0.022 & 0.004 & 0.021 & 0.004 & 0.012 & 0.002 & 0.012 & 0.002 & 0.474 & 0.969 & 2.729 \\
\hline SH-1 & bedded & 2.610 & 4.000 & 0.398 & 1.551 & 0.361 & 0.062 & 0.324 & 0.047 & 0.274 & 0.057 & 0.152 & 0.021 & 0.122 & 0.011 & 9.989 & 0.927 & 0.965 \\
\hline SH-2 & bedded & 0.435 & 0.694 & 0.082 & 0.290 & 0.064 & 0.015 & 0.060 & 0.010 & 0.064 & 0.014 & 0.038 & 0.005 & 0.035 & 0.005 & 1.811 & 0.881 & 1.289 \\
\hline SH-3 & bedded & 0.099 & 0.193 & 0.026 & 0.101 & 0.027 & 0.008 & 0.024 & 0.004 & 0.020 & 0.004 & 0.010 & 0.002 & 0.011 & 0.002 & 0.529 & 0.924 & 1.614 \\
\hline XBX-1 & bedded & 4.047 & 7.057 & 0.704 & 2.489 & 0.605 & 0.106 & 0.563 & 0.085 & 0.520 & 0.115 & 0.344 & 0.049 & 0.329 & 0.129 & 17.143 & 0.998 & 0.974 \\
\hline $\mathrm{ZY}-1$ & bedded & 0.069 & 0.131 & 0.016 & 0.064 & 0.015 & 0.003 & 0.013 & 0.002 & 0.013 & 0.003 & 0.007 & 0.001 & 0.007 & 0.001 & 0.344 & 0.953 & 1.314 \\
\hline ZY-2 & bedded & 2.778 & 4.503 & 0.462 & 1.792 & 0.451 & 0.078 & 0.445 & 0.064 & 0.359 & 0.075 & 0.200 & 0.029 & 0.177 & 0.055 & 11.469 & 0.947 & 0.946 \\
\hline CJG-1 & limestone & 0.375 & 0.726 & 0.082 & 0.293 & 0.068 & 0.011 & 0.058 & 0.009 & 0.053 & 0.010 & 0.028 & 0.004 & 0.023 & 0.003 & 1.745 & 1.000 & 0.939 \\
\hline EY-3 & limestone & 0.321 & 0.589 & 0.066 & 0.221 & 0.049 & 0.008 & 0.041 & 0.006 & 0.040 & 0.009 & 0.026 & 0.004 & 0.027 & 0.004 & 1.411 & 0.977 & 0.923 \\
\hline LSX-2 & limestone & 0.177 & 0.332 & 0.039 & 0.147 & 0.035 & 0.006 & 0.032 & 0.006 & 0.038 & 0.009 & 0.027 & 0.004 & 0.031 & 0.004 & 0.886 & 0.962 & 1.006 \\
\hline SDZ-1 & limestone & 0.414 & 0.775 & 0.095 & 0.343 & 0.082 & 0.013 & 0.072 & 0.010 & 0.058 & 0.012 & 0.033 & 0.005 & 0.033 & 0.005 & 1.951 & 0.942 & 0.922 \\
\hline XY-2 & limestone & 0.117 & 0.221 & 0.028 & 0.105 & 0.025 & 0.004 & 0.023 & 0.004 & 0.024 & 0.006 & 0.017 & 0.003 & 0.020 & 0.006 & 0.603 & 0.937 & 0.807 \\
\hline ZY-3 & limestone & 0.282 & 0.595 & 0.076 & 0.262 & 0.055 & 0.008 & 0.044 & 0.007 & 0.040 & 0.008 & & 0.004 & & 0.006 & & 0.977 & 0.857 \\
\hline MET-2 & nodular & 0.081 & 0.145 & 0.017 & 0.064 & 0.016 & 0.025 & 0.012 & 0.002 & 0.009 & 0.002 & 0.005 & 0.001 & 0.005 & 0.001 & 0.385 & 0.941 & 9.433 \\
\hline MET-3 & nodular & 0.135 & 0.304 & 0.041 & 0.160 & 0.042 & 0.042 & 0.040 & 0.006 & 0.037 & 0.007 & 0.020 & 0.003 & 0.020 & 0.003 & 0.862 & 0.979 & 5.471 \\
\hline MET-4 & & 0.225 & 0.457 & 0.057 & 0.221 & 0.058 & 0.052 & 0.054 & 0.008 & 0.041 & 0.007 & & 0.002 & 0.014 & 0.002 & 1.213 & 0.970 & 4.945 \\
\hline MET-6 & nodular & 1.678 & 3.151 & 0.360 & 1.414 & 0.361 & 0.110 & 0.353 & 0.056 & 0.341 & 0.070 & 0.193 & 0.029 & 0.188 & 0.029 & 8.333 & 0.976 & 1.660 \\
\hline
\end{tabular}

\subsubsection{Stable Silicon Isotope Compositions}

Nine bedded chert samples from four sections (EY, LSX, SH and ZY) were analyzed for silicon isotopes. The $\delta^{30} \mathrm{Si}$ values of the samples of the EY section are $1.1 \%$, $1.2 \%$ and $1.4 \%$, with an average value of $1.2 \%$. The $\delta^{30} \mathrm{Si}$ values of the two samples from the LSX section are $1.3 \%$ and $0.7 \%$ (Table 2). The $\delta^{30}$ Si values of the two samples from the SH section are $0.2 \%$ and $1.1 \%$. The $\delta^{30} \mathrm{Si}$ values of the two samples from the ZY section are $0.6 \%$ and $1.1 \%$. The average $\delta^{30} \mathrm{Si}$ value of the bedded chert samples is $0.91 \%$ (Table 2), which is similar to that of the bedded cherts samples from the LSX section (average 0.77\%o) [43]. The $\delta^{30} \mathrm{Si}$ values of the 14 chert samples from the ELB section are lower than those of the bedded cherts, ranging from $-0.4 \%$ to $0.7 \%$ (average $0.14 \%$ ) [22].

\section{Discussion}

\subsection{Origin of the Bedded Cherts}

The petrographic and geochemical evidences indicate that the bedded cherts of the Maokou Fm. mainly originate from biological processes. The lamination of the bedded cherts suggests a continued depositional process of siliceous materials. Furthermore, the bedded cherts contain numerous siliceous fossil debris, including ostracodes, spicules and radiolarians (Figures $4 \mathrm{E}$ and 5C,D), indicating a sedimentary accumulation of silicasecreting organisms, typically in the deep-water environment.

All the bedded chert samples were plotted in the biogenic-dominated zone in the Al-Fe-Mn ternary diagram, which also supported the biogenic origin of bedded cherts (Figure 6). The recorded depletion in Fe and Mn concentrations suggests that there are few significant signals of hydrothermal fluids $[1,17,44]$. In addition, the average values of $\mathrm{Al} /(\mathrm{Al}+\mathrm{Fe}+\mathrm{Mn})$ of the bedded cherts (0.56) are similar to the published values of biogenic cherts (ca. 0.6) $[17,45]$. The Si isotope compositions of bedded cherts also indicate that the siliceous materials originated from silica-secreting organisms in seawater. The silicon isotope fractionation is determined by the biological activity, precipitation rate, composition and temperature of the environmental solution during the inorganic precipitation of the dissolved silica [46-50]. The activities of radiolarians and sponges in shallow seas could preferentially remove $\delta^{28} \mathrm{Si}$, leading to the enrichment of $\delta^{30} \mathrm{Si}$ in the seawater [22,51]. Therefore, the high $\delta^{30} \mathrm{Si}$ values of Maokou bedded cherts (average $0.91 \%$ ), similar to those reported for seawater-derived cherts (average $0.77 \%$ ) [43], also suggest that the origin of the bedded cherts is mainly from silica-secreting organisms in seawater. 


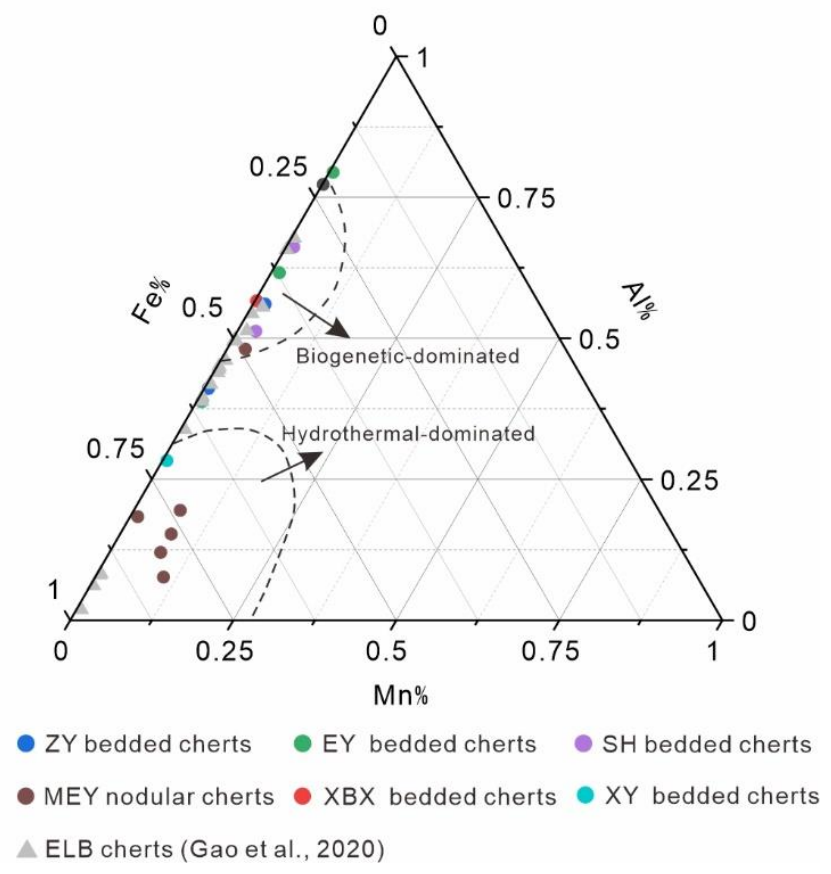

Figure 6. The ternary diagram of Al-Fe-Mn of the Maokou cherts in the Sichuan Basin. The hydrothermal- and biogenetic-dominated distribution zones are according to Adachi et al. [1].

The bedded cherts were mostly formed in a deep-water environment (e.g., troughs, slopes and basins) as suggested by the $\mathrm{Fe}_{2} \mathrm{O}_{3} / \mathrm{TiO}_{2}$ vs. $\mathrm{Al}_{2} \mathrm{O}_{3} /\left(\mathrm{Al}_{2} \mathrm{O}_{3}+\mathrm{Fe}_{2} \mathrm{O}_{3}\right)$ diagram (Figure 7), in which the bedded chert samples are plotted in the continental margin to pelagic fields [52]. Correspondingly, the location of the sections of these samples can also reflect the deep-water depositional environment (Figure 1B). Additionally, the flat REE patterns of bedded cherts (Table 3, Figure 8A) are comparable with those of limestone samples, suggesting that bedded cherts were formed in a seawater environment. However, the $\mathrm{Eu} / \mathrm{Eu}^{*}$ values of some bedded chert samples (e.g., LSX-1 and SH-3) display relatively high values (to a maximum of 2.7) in the SH and LSX sections, namely positive Eu anomalies, implying some degrees of hydrothermal influence. This is because Eu can be removed from other REEs by reducing from $\mathrm{Eu}^{3+}$ to $\mathrm{Eu}^{2+}$ under high temperature (especially $>250{ }^{\circ} \mathrm{C}$ ) and reducing conditions, leading to an increase of Eu in the sediments [53-55]. Therefore, we conclude that, although the bedded cherts largely originated from biological processes, the formation of some bedded cherts was influenced by hydrothermal activities.

\subsection{Origin of Nodular Cherts}

The nodular cherts from the Maokou Fm. are thought to be formed by hydrothermal effects, as evidenced by the petrographic and geochemical characteristics. The irregular non-stratified occurrence of nodular cherts in MEY and XY sections (Figures 1 and 3G-I) suggests a diagenetic process rather than a depositional process. The almost totally silicification of the calcareous bioclasts in the nodular cherts, with well-preserved ghost outlines (Figures $4 \mathrm{D}$ and $5 \mathrm{~A}$ ), indicates rapid metasomatism by Si-enriched diagenetic fluids, transferring from calcite to siliceous minerals [5]. In addition, the direct precipitation of hydrothermal silica was found in the XJG section near the basement deep fracture, which further explains the hydrothermal source of siliceous materials (Figure 4F). The nodular cherts are all located in the hydrothermal-dominated zone (Figure 6), suggesting a hydrothermal origin [1,17], which is consistent with the results that the average $\mathrm{Al} /(\mathrm{Al}+$ $\mathrm{Fe}+\mathrm{Mn})$ ratios $(\sim 0.15)$ of nodular chert samples are comparable with the reported values of hydrothermal cherts $(\sim 0.1)[17,45]$. Moreover, the obvious positive Eu anomalies, with a maximum value of 9.43 , further confirm that the nodular cherts were formed under the influence of the hydrothermal fluids or by the rapid process of siliceous metasomatism 
by hydrothermal fluids [53-55]. Additionally, the formation of dolomite particles in the host limestone near the nodular cherts may be related to the same hydrothermal activity (Figure 4A). Thus, we conclude that the hydrothermal activities were the main triggering factor for the formation of the Maokou nodular cherts.

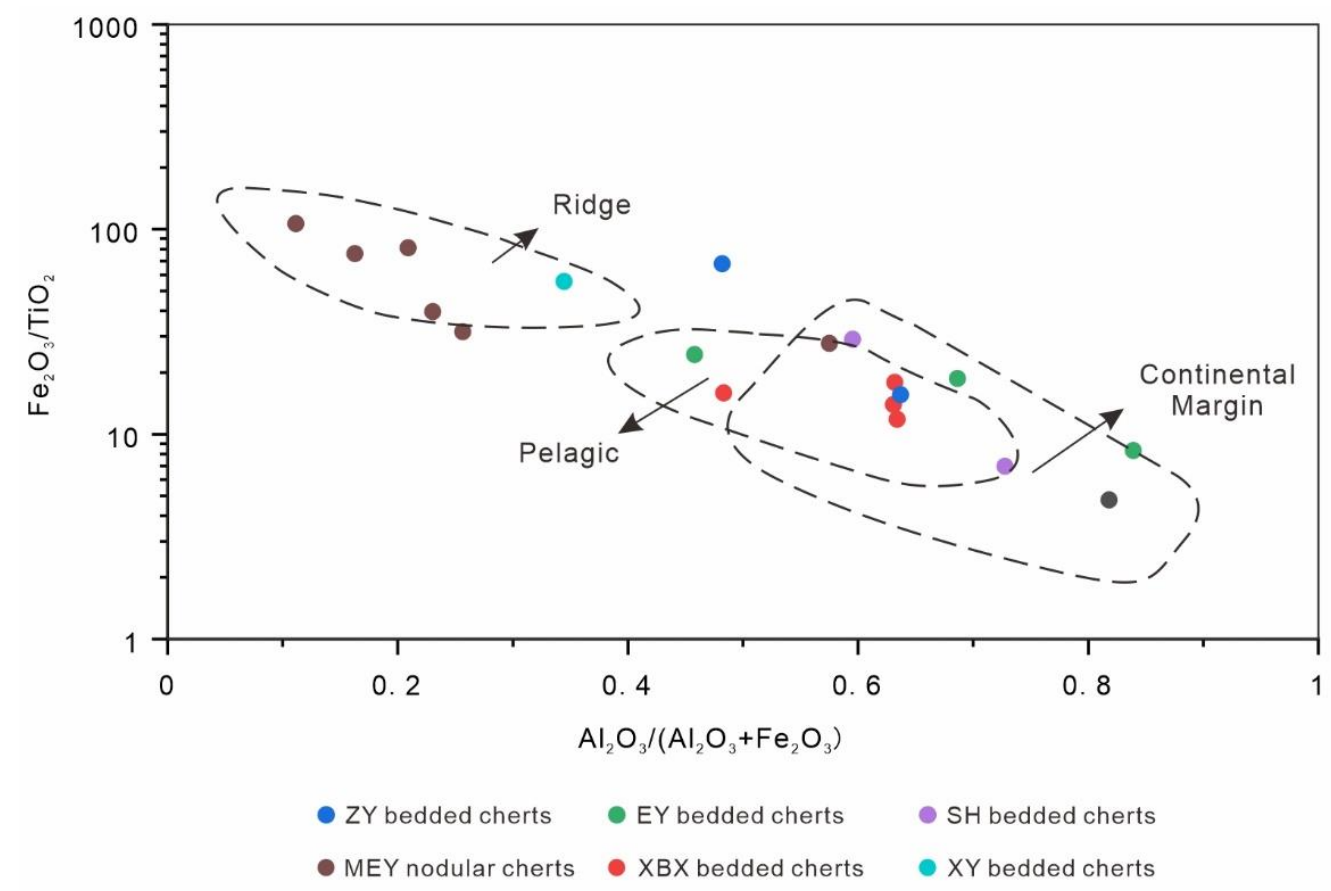

Figure 7. $\mathrm{Fe}_{2} \mathrm{O}_{3} / \mathrm{TiO} 2$ versus $\mathrm{Al}_{2} \mathrm{O}_{3} /\left(\mathrm{Al}_{2} \mathrm{O}_{3}+\mathrm{Fe}_{2} \mathrm{O}_{3}\right)$ diagram for the Maokou cherts in the Sichuan Basin.
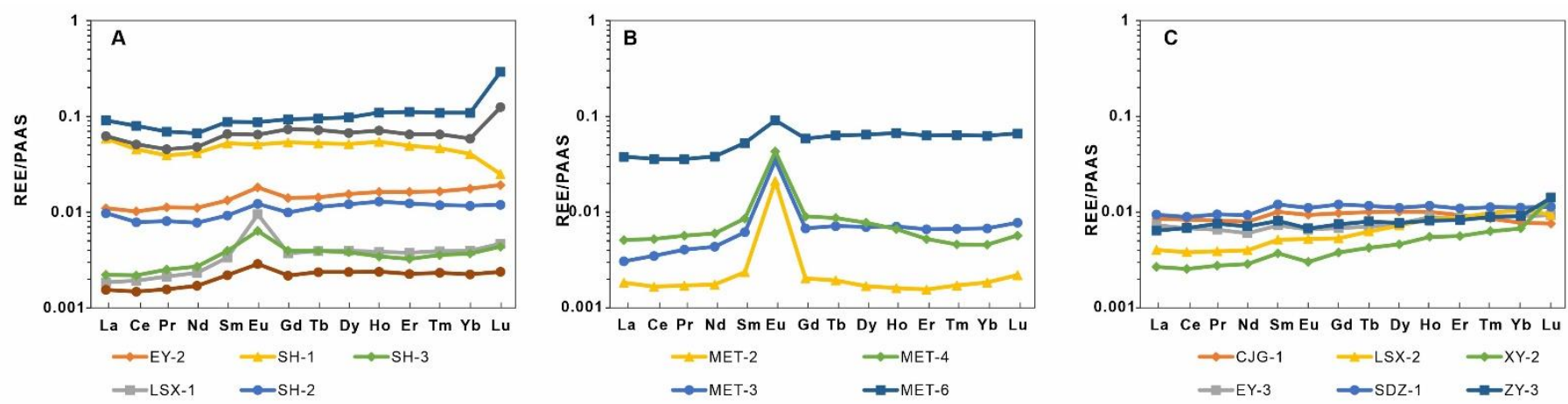

Figure 8. PAAS-normalized REE patterns of cherts and limestones. (A) Bedded cherts of Maokou Fm.; (B) nodular cherts of Maokou Fm.; (C) limestones of Maokou Fm.

$\mathrm{Si}$ isotopes can further confirm that the hydrothermal fluids have influenced the formation of the nodular cherts (Figure 9). The $\delta^{30} \mathrm{Si}$ values of the nodular chert samples from the Erlangba (ELB) section (average $0.14 \%$ ) are significantly lower than those of the bedded cherts samples (average 0.79\%) [22], suggesting hydrothermal siginals. The low $\delta^{30} \mathrm{Si}$ values might be caused by the rapid precipitation of the supersaturated dissolved silica in the hydrothermal fluids, as it forms an amorphous siliceous gel once cooled. A massive amount of silicon isotope fractionation of $\triangle^{30} \mathrm{Si}$ (solid-aqueous) yields during this process $[40,49]$. Therefore, cherts of hydrothermal origin usually have a low $\delta^{30} \mathrm{Si}$ value, which is consistent with the suggestion stated above. 


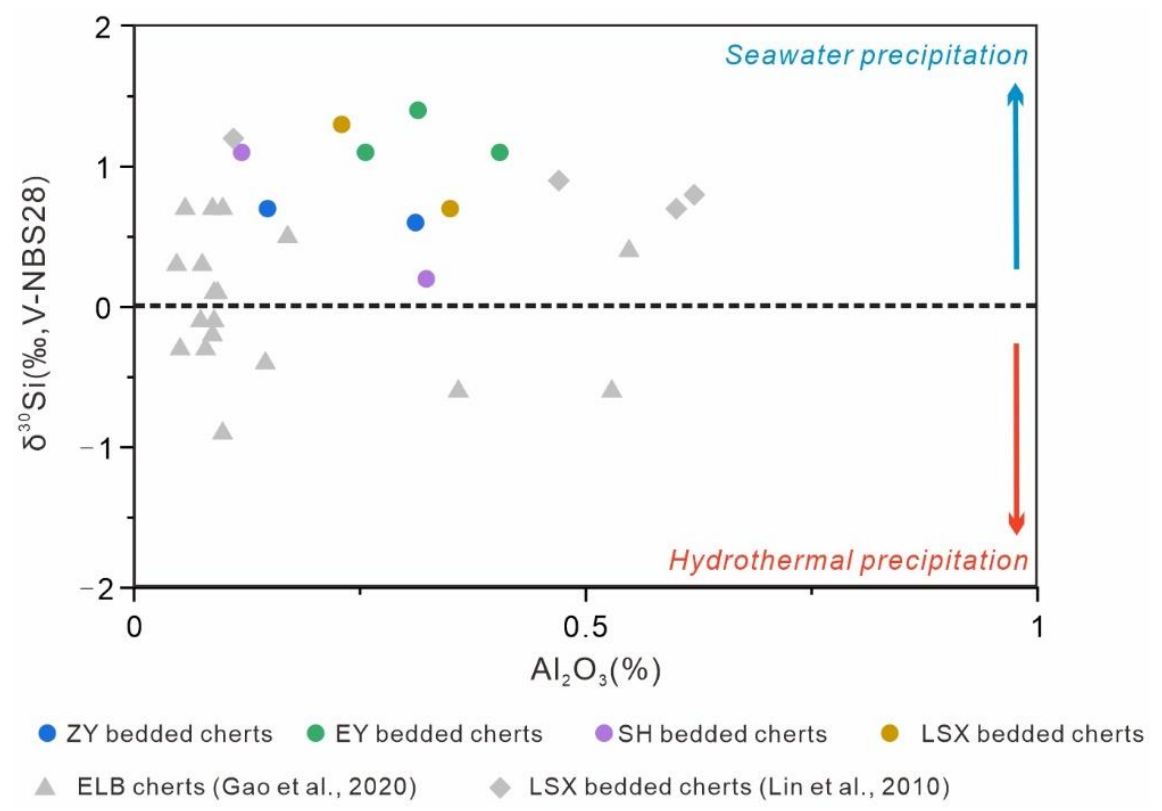

Figure 9. Correlation of $\delta^{30} \mathrm{Si}$ and $\mathrm{Al}_{2} \mathrm{O}_{3}$ concentrations of the Maokou cherts (data of ELB cherts from [22]; data of LSX cherts from [43]).

As shown in Figure 7, all the nodular chert samples fall into the "ridge" zone in the $\mathrm{Fe}_{2} \mathrm{O}_{3} / \mathrm{TiO}_{2}$ vs. $\mathrm{Al}_{2} \mathrm{O}_{3} /\left(\mathrm{Al}_{2} \mathrm{O}_{3}+\mathrm{Fe}_{2} \mathrm{O}_{3}\right)$ diagram [52], which is in agreement with the facts that the paleogeographic locations of the MEY and XY sections are adjacent to the active deep faults that have experienced significant hydrothermal activity (Figure 1C). These deep faults were activated because of the intense tectonic movements related to the ELIP during the late Guadalupian $[29,56]$, accompanying massive hydrothermal fluids venting into the shallow-buried carbonate stratum or deep ocean seafloor. Therefore, the nodular cherts were formed by siliceous precipitation via cooling of the Si-enriched hydrothermal fluids or by the rapid hydrothermal metasomatism of the host carbonate rocks.

\subsection{The Formation Mechanism of the Maokou Cherts}

As noted above, the nodular cherts were mainly formed under the influence of hydrothermal fluids, and the bedded cherts originated from the biological processes with some extent of hydrothermal effects. Thus, we believe that the bedded and nodular cherts may share the same source, which is associated with the hydrothermal activities related to the ELIP events. The sedimentary environment was the main factor that led to the different occurrences of Maokou cherts. The nodular cherts occurred in the shallow-water carbonate platform and the bedded cherts occurred in the deep-water environments (e.g., trough, slope and shelf).

Despite the bedded cherts being significantly characterized by signals of biogenetic origins, some geochemical evidence (e.g., Eu anomalies) shows the effects of hydrothermal fluids. The bedded chert samples are all plotted in the upwelling zone of the $\mathrm{Co} \times \mathrm{Mn}$ vs. $\mathrm{Cd} / \mathrm{Mo}$ diagram (Figure 10). This is because the sediments of upwellings are generally featured by high Cd/Mo values and low Co $\times$ Mn values [57,58]. The high primary productivity of upwellings leads to an increase in Cd contents through the flourishing of Cd-rich plankton, in contrast to the constant contents of the less bio-sensitive Mo elements [59]. Alternatively, the low contents of Co and Mn are attributed to their decrease in the oxygenated upwellings [60]. In contrast, the nodular chert samples fall outside the upwelling zones (Figure 10), which also indicates that the formation of nodular cherts did not occur in a deep-water environment and was directly associated with the hydrothermal fluids which carried high Mn contents. 


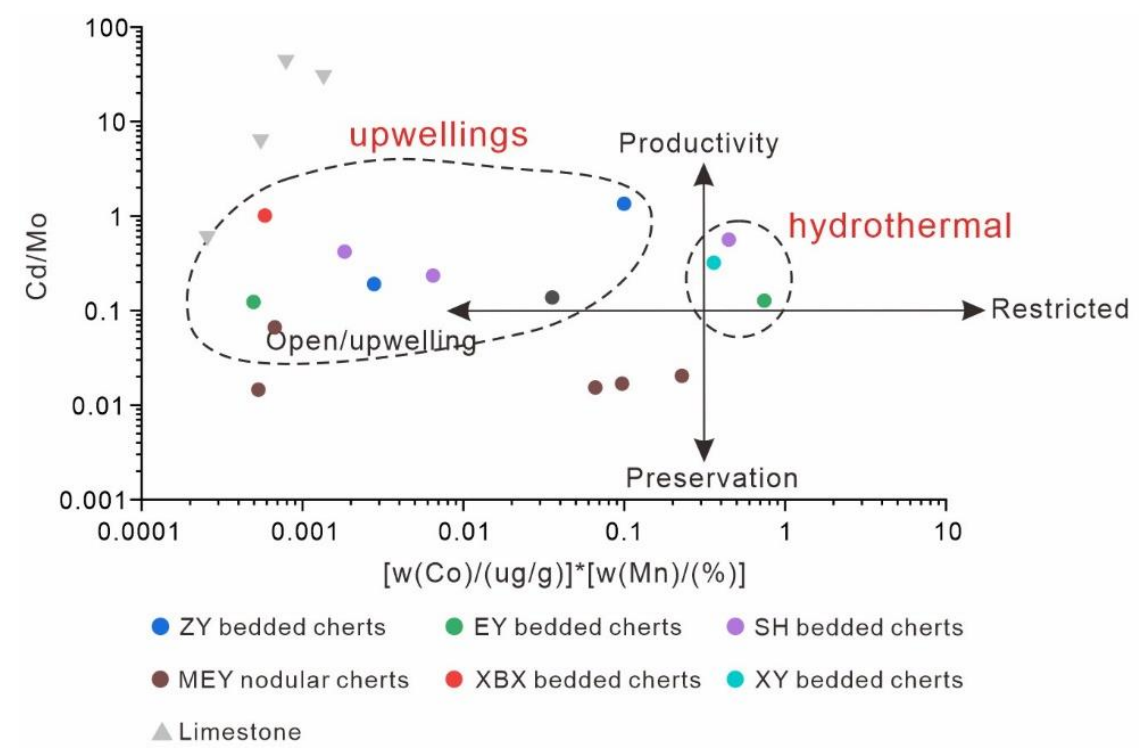

Figure 10. Co*Mn versus Cd/Mo diagram for the Maokou cherts to identify upwelling settings.

The upwellings in the Upper Yangtze Block was caused by the venting of hightemperature hydrothermal fluids from deep faults during Guadalupian [5], which is entirely different from the upwellings caused by the melting of polar glaciers on the northwestern edge of Pangea during the Mid-Late Permian [7,8]. The activity of ELIP triggered strong tectonic movements, which led to the activation of deep faults and the overflow of hydrothermal fluids. The hydrothermal fluids were the results of the mixing of magmatic-derived fluids and modified seawater. Due to the high temperature of the hydrothermal fluids from under the seafloor, the cold bottom seawater was heated to reduce its density and went upward to form upwellings, namely volcanogenic upwellings [61-63]. The upwellings carried a large number of nutrients (including $\mathrm{N}, \mathrm{P}, \mathrm{Ba}$ and $\mathrm{H}_{4} \mathrm{SiO}_{4}$ ), which could promote the proliferation of siliceous organisms. These biologically sourced silica settled on the bottom of the seawater with the death of organisms, so bedded cherts were formed in deep water environments such as troughs [64-66] (Figure 11). In addition, the silicon-rich seawater could pour into the shallow-buried Maokou carbonate strata adjected to the deep-water area due to the power from the upwellings. Silicon-rich fluids tend to first metasomatize the argillaceous components of the carbonate rocks to form a siliceous nucleus, and then they grow into siliceous rocks under specific conditions [5,22] (Figure 11). The nucleation and growth of the siliceous rocks were accelerated when they were directly affected or heated by the hydrothermal fluid, forming large nodular or striped cherts. This process mainly occurred in the sedimentary environment of shallow-water carbonate platform, resulting in the facts that nodular cherts mainly distributed in shallower-water platform sediments (Figure 11).

Therefore, we believe that the bedded cherts of the Maokou Formation were formed by biological process caused by the upwelling related to tectonic-hydrothermal activities. Some of the nodular cherts might be directly metasomatized by hydrothermal fluids, and the others may have been the results of the water-rock reaction by the silicon-rich fluid in the strata, which had a similar siliceous source to the bedded chert. 


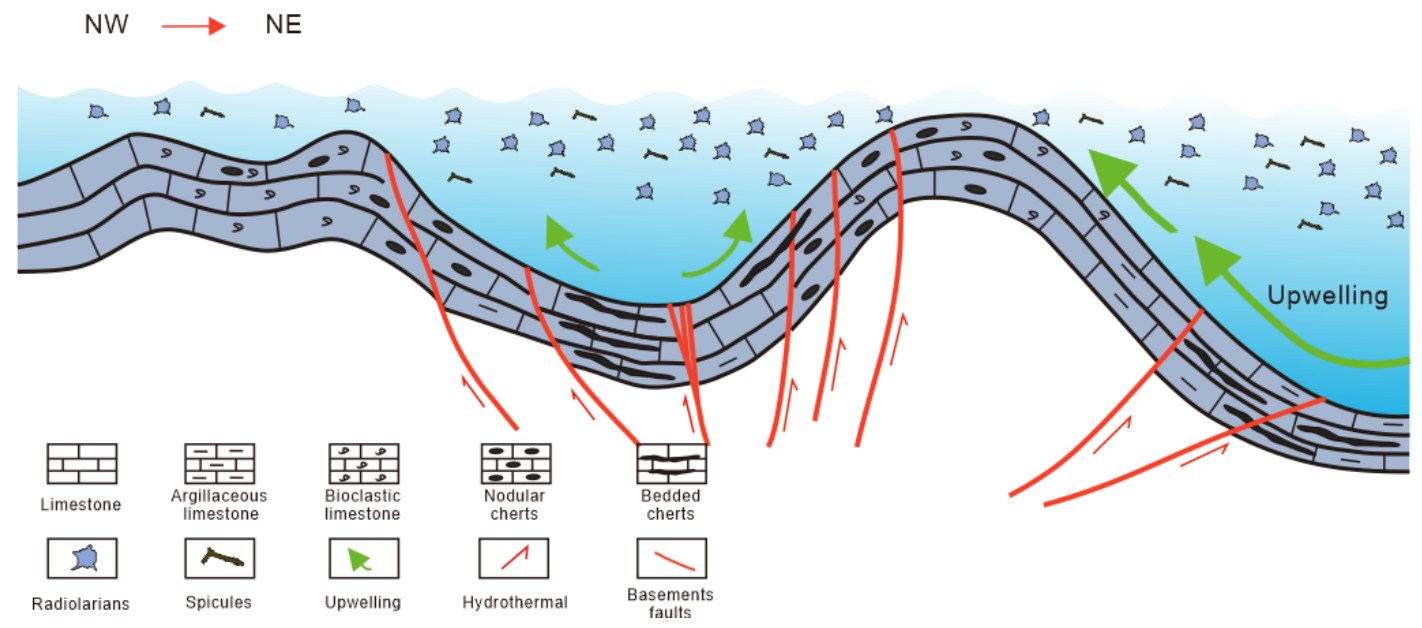

Figure 11. Conceptual models showing the formation mechanism of the Maokou cherts in the Sichuan Basin (the position of the cross-section is shown in Figure 1C). The bedded cherts of biological origin are mainly distributed in the deep-water environment, whereas the nodular cherts are mainly distributed in the shallow water platform environment.

\section{Conclusions}

In this study, the petrographic and geochemical data of cherts samples from six outcrop sections were presented to study the genesis of different types of cherts in the Maokou Formation in the Sichuan Basin.

The Maokou cherts occurred in nodular and bedded forms. The bedded cherts were mainly formed in a deep-water environment and are mainly formed by the biogenetic processes related to volcanogenic upwellings. Some bedded chert samples near the basement fractures show weak hydrothermal characteristics evidenced from geochemical data, suggesting that they were affected by the hydrothermal fluids. Nodular cherts commonly have characteristics of hydrothermal origins. Some nodular cherts were formed through direct hydrothermal metasomatism, and others formed from a similar siliceous source to bedded cherts that were affected by the hydrothermal fluids to a larger degree. To summarize, both the bedded and nodular Maokou cherts were influenced by hydrothermal activities, and both had a strong relationship with the tectonic movements and eruptions of the ELIP events.

Author Contributions: Conceptualization, H.Z.; methodology, H.T.; investigation, H.Z. and J.W.; resources, X.Y.; data curation, K.S.; writing—original draft preparation, H.Z.; writing—review and editing, Y.D.; supervision, B.L. and Y.D.; funding acquisition, K.L. and Q.Q. All authors have read and agreed to the published version of the manuscript.

Funding: This research was funded by the National Natural Science Foundation of China, grant number U19B6003 and the Wuxi Research Institute of Petroleum Geology, SINPEC, grant number 33550007-19-ZC0613-0085.

Acknowledgments: Thanks to Hangyu Liu, Xuefeng Zhang and Yuanchong Wang from Peking University for their help in writing this article.

Conflicts of Interest: The authors declare no conflict of interest.

\section{References}

1. Adachi, M.; Yamamoto, K.; Sugisaki, R. Hydrothermal chert and associated siliceous rocks from the northern Pacific their geological significance as indication od ocean ridge activity. Sediment. Geol. 1986, 47, 125-148. [CrossRef]

2. Kato, Y.; Nakao, K.; Isozaki, Y. Geochemistry of Late Permian to Early Triassic pelagic cherts from southwest Japan: Implications for an oceanic redox change. Chem. Geol. 2002, 182, 15-34. [CrossRef]

3. Dongying, S.; Wenchen, X. Identification of the Guadalupian-Lopingian boundary in the Permian in a bedded chert sequence, South China. Palaeogeogr. Palaeoclimatol. Palaeoecol. 2006, 236, 272-289. [CrossRef]

4. Qiu, Z.; Wang, Q. Geochemical evidence for submarine hydrothermal origin of the Middle-Upper Permian chert in Laibin of Guangxi, China. Sci. China Earth Sci. 2011, 54, 1011-1023. [CrossRef] 
5. $\quad$ Dong, Y.; Xu, S.; Wen, L.; Chen, H.; Fu, S.; Zhong, Y.; Wang, J.; Zhu, P.; Cui, Y. Tectonic control of Guadalupian-Lopingian cherts in northwestern Sichuan Basin, South China. Palaeogeogr. Palaeoclim. Palaeoecol. 2020, 557, 109915. [CrossRef]

6. Murchey, B.L.; Jones, D.L. A mid-Permian chert event: Widespread deposition of biogenic siliceous sediments in coastal, island arc and oceanic basins. Palaeogeogr. Palaeoclim. Palaeoecol. 1992, 96, 161-174. [CrossRef]

7. Beauchamp, B.; Baud, A. Growth and demise of Permian biogenic chert along northwest Pangea: Evidence for end-Permian collapse of thermohaline circulation. Palaeogeogr. Palaeoclim. Palaeoecol. 2002, 184, 37-63. [CrossRef]

8. Gates, L.M.; James, N.P.; Beauchamp, B. A glass ramp: Shallow-water Permian spiculitic chert sedimentation, Sverdrup Basin, Arctic Canada. Sediment. Geol. 2004, 168, 125-147. [CrossRef]

9. Vattanasak, H.; Chonglakmani, C.; Feng, Q.; Morley, C.K. Chert geochemistry, depositional setting, stratigraphic and structural significance for the Permian Nong Pong Formation, Khao Khwang Fold and Thrust Belt, Saraburi, Thailand. J. Asian Earth Sci. 2020, 191, 104234. [CrossRef]

10. Wu, W.; Liu, W.; Mou, C.; Liu, H.; Qiao, Y.; Pan, J.; Ning, S.; Zhang, X.; Yao, J.; Liu, J. Organic-rich siliceous rocks in the upper Permian Dalong Formation (NW middle Yangtze): Provenance, paleoclimate and paleoenvironment. Mar. Pet. Geol. 2020, 123, 104728. [CrossRef]

11. Kametaka, M.; Takebe, M.; Nagai, H.; Zhu, S.; Takayanagi, Y. Sedimentary environments of the Middle Permian phosphorite-chert complex from the northeastern Yangtze platform, China; the Gufeng Formation: A continental shelf radiolarian chert. Sediment. Geol. 2005, 174, 197-222. [CrossRef]

12. Yao, X.; Zhou, Y.; Li, S.; Li, D. Research status and advances in chert and Permian chert event. Adv. Earth Sci. 2013, 28, 1189-1200.

13. Liao, Z.-W.; Hu, W.-X.; Fu, X.-G.; Hu, Z.-Y. Geochemistry of upper Permian siliceous rocks from the Lower Yangtze region, southeastern China: Implications for the origin of chert and Permian ocean chemistry. Pet. Sci. 2018, 16, 252-266. [CrossRef]

14. Yu, Y.; Lin, L.; Deng, X.; Wang, Y.; Li, Y.; Guo, Y. Geochemical features of the Middle-Upper Permian cherts and implications for origin, depositional environment in the Sichuan Basin, SW China. Geol. J. 2020, 55, 1493-1506. [CrossRef]

15. Tréguer, P.; Nelson, D.M.; Van Bennekom, A.J.; DeMaster, D.J.; Leynaert, A.; Quéguiner, B. The Silica Balance in the World Ocean: A Reestimate. Science 1995, 268, 375-379. [CrossRef]

16. Bostrom, K.; Peterson, M.N.A.; Joensuu, O.; Fisher, D.E. Aluminum-poor ferromanganoan sediments on active oceanic ridges. J. Geophys. Res. Space Phys. 1969, 74, 3261-3270. [CrossRef]

17. Yamamoto, K. Geochemical characteristics and depositional environments of cherts and associated rocks in the Franciscan and Shimanto Terranes. Sediment. Geol. 1987, 52, 65-108. [CrossRef]

18. Maliva, R.G.; Knoll, A.H.; Siever, R. Secular Change in Chert Distribution: A Reflection of Evolving Biological Participation in the Silica Cycle. Palaios 1989, 4, 519. [CrossRef]

19. Yu, K.; Zhang, Z.; Cao, Y.; Qiu, L.; Zhou, C.; Cheng, D.; Sun, P.; Yang, Y. Origin of biogenic-induced cherts from Permian alkaline saline lake deposits in the NW Junggar Basin, NW China: Implications for hydrocarbon exploration. J. Asian Earth Sci. 2021, 211, 104712. [CrossRef]

20. Matysik, M.; Stemmerik, L.; Olaussen, S.; Rameil, N.; Gianotten, I.P.; Brunstad, H. Cherts, spiculites, and collapse brecciasPorosity generation in upper Permian reservoir rocks, Gohta discovery, Loppa High, south-western Barents Sea. Mar. Pet. Geol. 2021, 128, 105043. [CrossRef]

21. Yao, X.; Li, S.; Zhou, Y.; Hinnov, L.A. Hydrothermal Origin of Early Permian Chert Nodules in the Central North China Craton Linked to Northern Margin Cratonic Activation. Acta Geol. Sin. 2021, 95, 541-557. [CrossRef]

22. Gao, P.; He, Z.; Lash, G.G.; Li, S.; Xiao, X.; Han, Y.; Zhang, R. Mixed seawater and hydrothermal sources of nodular chert in Middle Permian limestone on the eastern Paleo-Tethys margin (South China). Palaeogeogr. Palaeoclim. Palaeoecol. 2020, 551, 109740. [CrossRef]

23. Kamata, Y.; Maezawa, A.; Hara, H.; Ueno, K.; Hisada, K.-I.; Sardsud, A.; Charoentitirat, T.; Charusiri, P. Basaltic activity preserved in an Upper Permian radiolarian chert from the Paleo-Tethys in the Inthanon Zone, northern Thailand. J. Asian Earth Sci. 2012, 61, 51-61. [CrossRef]

24. Zhu, Z.-Y.; Jiang, S.-Y.; Liu, G.-X.; Zhao, K.-D. Precise dating of the Middle Permian: Zircon U-Pb geochronology from volcanic ash beds in the basal Gufeng Formation, Yangtze region, South China. Gondwana Res. 2013, 23, 1599-1606. [CrossRef]

25. Wignall, P.B.; Sun, Y.; Bond, D.P.G.; Izon, G.; Newton, R.J.; Védrine, S.; Widdowson, M.; Ali, J.R.; Lai, X.; Jiang, H.; et al. Volcanism, Mass Extinction, and Carbon Isotope Fluctuations in the Middle Permian of China. Science 2009, 324, 1179-1182. [CrossRef]

26. Huang, J.; Liu, J.; Zhang, Y.; Chang, H.; Shen, Y.; Huang, F.; Qin, L. Cr isotopic composition of the Laobao cherts during the Ediacaran-Cambrian transition in South China. Chem. Geol. 2018, 482, 121-130. [CrossRef]

27. He, D.; Li, D.; Zhang, G.; Zhao, L.; Fan, C.; Lu, R.; Wen, Z. Formation and evolution of multi-cycle superposed Sichuan Basin, China. Chin. J. Geol. 2011, 46, 589-606.

28. Zheng, H.; Liu, B. Structural Differentiation and Sedimentary System of the Permian Sichuan Cratonic Basin; René, M., Aiello, G., el Bahariya, G., Eds.; IntechOpen: London, UK, 2020; p. 189.

29. Shellnutt, J.G. The Emeishan large igneous province: A synthesis. Geosci. Front. 2014, 5, 369-394. [CrossRef]

30. He, B.; Xu, Y.-G.; Guan, J.-P.; Zhong, Y.-T. Paleokarst on the top of the Maokou Formation: Further evidence for domal crustal uplift prior to the Emeishan flood volcanism. Lithos 2010, 119, 1-9. [CrossRef]

31. He, B.; Xu, Y.-G.; Chung, S.-L.; Xiao, L.; Wang, Y. Sedimentary evidence for a rapid, kilometer-scale crustal doming prior to the eruption of the Emeishan flood basalts. Earth Planet. Sci. Lett. 2003, 213, 391-405. [CrossRef] 
32. Zhu, B.; Guo, Z.; Zhang, S.; Ukstins, I.; Du, W.; Liu, R. What triggered the early-stage eruption of the Emeishan large igneous province? Bulletin 2019, 131, 1837-1856. [CrossRef]

33. Zheng, H.; Ma, Y.; Chi, G.; Qing, H.; Liu, B.; Zhang, X.; Shen, Y.; Liu, J.; Wang, Y. Stratigraphic and Structural Control on Hydrothermal Dolomitization in the Middle Permian Carbonates, Southwestern Sichuan Basin (China). Minerals 2019,9 , 32. [CrossRef]

34. Scotese, C.; Schettino, A. Late Permian-Early Jurassic paleogeography of western Tethys and the world. In Permo-Triassic Salt Provinces of Europe, North Africa and the Atlantic Margins; Elsevier: Amsterdam, The Netherlands, 2017; pp. 57-95.

35. Wei, H.; Wei, X.; Qiu, Z.; Song, H.; Shi, G. Redox conditions across the G-L boundary in South China: Evidence from pyrite morphology and sulfur isotopic compositions. Chem. Geol. 2016, 440, 1-14. [CrossRef]

36. Zhang, B.; Yao, S.; Wignall, P.B.; Hu, W.; Ding, H.; Liu, B.; Ren, Y. Widespread coastal upwelling along the Eastern Paleo-Tethys Margin (South China) during the Middle Permian (Guadalupian): Implications for organic matter accumulation. Mar. Pet. Geol. 2018, 97, 113-126. [CrossRef]

37. Li, M. Report on Natural Gas Exploration and Development Prospect of Sichuan Basin Predicted by Magnetic and Gravity Data; Geophysical Prospecting Team of Sichuan Bureau of Geology and Mineral Resources: Chengdu, China, 1995.

38. Yang, Y.; Yang, Y.; Wen, L.; Zhang, X.; Chen, C.; Chen, K.; Zhang, Y.; Di, G.; Wang, H.; Xie, C. New progress and prospect of Middle Permian natural gas exploration in the Sichuan Basin. Nat. Gas Ind. B 2021, 8, 35-47. [CrossRef]

39. McLennan, S.M. Rare earth elements in sedimentary rocks: Influence of provenance and sedimentary processes. Rev. Mineral. Geochem. 1989, 21, 169-200.

40. Li, D.; Bancroft, G.M.; Fleet, M.E.; Feng, X.H. Silicon K-edge XANES spectra of silicate minerals. Phys. Chem. Miner. 1995, 22, 115-122. [CrossRef]

41. Ding, T.; Wan, D.; Wang, C.; Zhang, F. Silicon isotope compositions of dissolved silicon and suspended matter in the Yangtze River, China. Geochim. Cosmochim. Acta 2004, 68, 205-216. [CrossRef]

42. Li, Y.; Hou, K.; Wan, D.; Zhang, Z.; Yue, G. Precambrian banded iron formations in the North China Craton: Silicon and oxygen isotopes and genetic implications. Ore Geol. Rev. 2014, 57, 299-307. [CrossRef]

43. Lin, L.B.; Chen, H.D.; Zhu, L.D. The origin and geochemical characteristics of Maokou Formation silicalites in the eastern Sichuan Basin. Acta Geol. Sin. 2010, 84, 500-507.

44. Liu, Z.; Zhuang, X.G.; Teng, G.E.; Xie, X.M.; Yin, L.M.; Bian, L.Z.; Feng, Q.L.; Algeo, T.J. The Lower Cambrian Niutitang Formation at Yangtiao (Guizhou, Sw China): Organic Matter Enrichment, Source Rock Potential, and Hydrothermal Influences. J. Pet. Geol. 2015, 38, 411-432. [CrossRef]

45. Aitchison, J.; Flood, P. Geochemical constraints on the depositional setting of Palaeozoic cherts from the New England orogen, NSW, eastern Australia. Mar. Geol. 1990, 94, 79-95. [CrossRef]

46. Abraham, K.; Hofmann, A.; Foley, S.; Cardinal, D.; Harris, C.; Barth, M.; André, L. Coupled silicon-oxygen isotope fractionation traces Archaean silicification. Earth Planet. Sci. Lett. 2010, 301, 222-230. [CrossRef]

47. Oelze, M.; von Blanckenburg, F.; Hoellen, D.; Dietzel, M.; Bouchez, J. Si stable isotope fractionation during adsorption and the competition between kinetic and equilibrium isotope fractionation: Implications for weathering systems. Chem. Geol. 2014, 380, 161-171. [CrossRef]

48. Oelze, M.; von Blanckenburg, F.; Bouchez, J.; Hoellen, D.; Dietzel, M. The effect of Al on Si isotope fractionation investigated by silica precipitation experiments. Chem. Geol. 2015, 397, 94-105. [CrossRef]

49. Geilert, S.; Vroon, P.Z.; Roerdink, D.; Van Cappellen, P.; van Bergen, M.J. Silicon isotope fractionation during abiotic silica precipitation at low temperatures: Inferences from flow-through experiments. Geochim. Cosmochim. Acta 2014, 142, 95-114. [CrossRef]

50. Geilert, S.; Vroon, P.Z.; Keller, N.S.; Gudbrandsson, S.; Stefánsson, A.; van Bergen, M.J. Silicon isotope fractionation during silica precipitation from hot-spring waters: Evidence from the Geysir geothermal field, Iceland. Geochim. Cosmochim. Acta 2015, 164, 403-427. [CrossRef]

51. De La Rocha, C.L.; Brzezinski, M.A.; Deniro, M.J.; Shemesh, A. Silicon-isotope composition of diatoms as an indicator of past oceanic change. Nature 1998, 395, 680-683. [CrossRef]

52. Murray, R.W. Chemical criteria to identify the depositional environment of chert: General principles and applications. Sediment. Geol. 1994, 90, 213-232. [CrossRef]

53. Bau, M. Rare-earth element mobility during hydrothermal and metamorphic fluid-rock interaction and the significance of the oxidation state of europium. Chem. Geol. 1991, 93, 219-230. [CrossRef]

54. Bolhar, R.; Van Kranendonk, M. A non-marine depositional setting for the northern Fortescue Group, Pilbara Craton, inferred from trace element geochemistry of stromatolitic carbonates. Precambrian Res. 2007, 155, 229-250. [CrossRef]

55. Tostevin, R.; Shields, G.A.; Tarbuck, G.M.; He, T.; Clarkson, M.; Wood, R.A. Effective use of cerium anomalies as a redox proxy in carbonate-dominated marine settings. Chem. Geol. 2016, 438, 146-162. [CrossRef]

56. He, B.; Xu, Y.-G.; Huang, X.-L.; Luo, Z.-Y.; Shi, Y.-R.; Yang, Q.-J.; Yu, S.-Y. Age and duration of the Emeishan flood volcanism, SW China: Geochemistry and SHRIMP zircon U-Pb dating of silicic ignimbrites, post-volcanic Xuanwei Formation and clay tuff at the Chaotian section. Earth Planet. Sci. Lett. 2007, 255, 306-323. [CrossRef]

57. Sweere, T.; Boorn, S.V.D.; Dickson, A.J.; Reichart, G.-J. Definition of new trace-metal proxies for the controls on organic matter enrichment in marine sediments based on Mn, Co, Mo and Cd concentrations. Chem. Geol. 2016, 441, 235-245. [CrossRef] 
58. Shang, F.; Zhu, Y.; Hu, Q.; Wang, Y.; Li, Y.; Li, W.; Liu, R.; Gao, H. Factors controlling organic-matter accumulation in the Upper Ordovician-Lower Silurian organic-rich shale on the northeast margin of the Upper Yangtze platform: Evidence from petrographic and geochemical proxies. Mar. Pet. Geol. 2020, 121, 104597. [CrossRef]

59. Nakagawa, S.; Santos, E. Methodological issues and advances in biological meta-analysis. Evol. Ecol. 2012, $26,1253-1274$. [CrossRef]

60. Saitoh, M.; Isozaki, Y.; Ueno, Y.; Yoshida, N.; Yao, J.; Ji, Z. Middle-Upper Permian carbon isotope stratigraphy at Chaotian, South China: Pre-extinction multiple upwelling of oxygen-depleted water onto continental shelf. J. Asian Earth Sci. 2013, 67-68, 51-62. [CrossRef]

61. Vogt, P.R. Volcanogenic upwelling of anoxic, nutrient-rich water: A possible factor in carbonate-bank/reef demise and benthic faunal extinctions? Geol. Soc. Am. Bull. 1989, 101, 1225-1245. [CrossRef]

62. Racki, G.; Cordey, F. Radiolarian palaeoecology and radiolarites: Is the present the key to the past? Earth-Sci. Rev. 2000, 52, 83-120. [CrossRef]

63. Wilson, B.; Hayek, L.-A.C. Planktonic foraminifera as indicators of oceanographic complexity on the southern Caribbean Sea continental shelf. Estuar. Coast. Shelf Sci. 2019, 228, 106359. [CrossRef]

64. Rosenbauer, R.J.; Bischoff, J.L. Uptake and transport of heavy metals by heated seawater: A summary of the experimental results. In Hydrothermal Processes at Seafloor Spreading Centers; Springer: Berlin, Germany; pp. 177-197.

65. Moore, T.C., Jr. Biogenic silica and chert in the Pacific Ocean. Geology 2008, 36, 975-978. [CrossRef]

66. Shen, B.; Ma, H.; Ye, H.; Lang, X.; Pei, H.; Zhou, C.; Zhang, S.; Yang, R. Hydrothermal origin of syndepositional chert bands and nodules in the Mesoproterozoic Wumishan Formation: Implications for the evolution of Mesoproterozoic cratonic basin, North China. Precambrian Res. 2018, 310, 213-228. [CrossRef] 